\author{
NBER WORKING PAPER SERIES \\ $\mathrm{ON}$ \\ HISTORICAL FACTORS IN LONG RUN GROWTH
}

THE STABILITY OF THE

AMERICAN BUSINESS ELITE

Peter Temin

Historical Paper 110

\author{
NATIONAL BUREAU OF ECONOMIC RESEARCH \\ 1050 Massachusetts Avenue \\ Cambridge, MA 02138 \\ December 1998
}

I would like to thank Regina Chen, John Kang, Sung Kim, and Yehbin Song for research assistance under MIT's Undergraduate Research Opportunities Program (UROP). Any opinions expressed are those of the authors and not those of the National Bureau of Economic Research.

(C) 1998 by Peter Temin. All rights reserved. Short sections of text, not to exceed two paragraphs, may be quoted without explicit permission provided that full credit, including (C) notice, is given to the source. 
The Stability of the American Busniess Elite

Peter Temin

NBER Historical Paper No. 110

December 1998

Development of the American Economy

ABSTRACT

This paper begins the task of explaining why the American business elite has remained white, male and mostly native-born Protestants for a century, as verified in a previous paper (Temin, 1997). I argue that the evidence is inconsistent with the hypotheses that the stability is due to discrimination on the job or to principal-agent factors. The most likely explanation is that this demographic group makes the best business managers. I suggest that this in turn is not because they are inherently superior, but because they have had access to superior education, a result of past discrimination.

Peter Temin

Department of Economics

Room E52-280A

MIT

50 Memorial Drive

Cambridge, MA 02142-1347

and NBER

ptemin@mit.edu 
There have always been business firms in the United States, but the modern managerial firm only came into existence in the late nineteenth century (Chandler, 1977, 1990). These firms have dominated economic life in this country for the past 100 years, although the current largest firms are not the same as those in 1900 (Hannah, 1998a, 1998b). The leaders of these firms in 1900 were male, white, and mostly native-born Protestants from good families. And today they are still male, white, and mostly native-born Protestants from good families. Given the vast changes in large firms, politics, economics, and the ethnic and demographic composition of the American population and workforce that have occurred in the twentieth century, this paper asks why these leaders continue to be drawn from one particular group.

This is a recurrent question. Every study of this topic finds that the ethnic and demographic composition of the business elite has not changed during the twentieth century. And most studies state that this stability will not last. They typically portray their study as the last generation for which their observations would be true. Conditions have been changing, and the expectations of these various authors may have been rational. But the composition of the American business elite has not changed.

I provide evidence that bear on three possible hypotheses for this persistence. The first hypothesis is that there is discrimination in the selection of business leaders; other groups have been excluded from the pool from which these leaders are drawn. Second, the selection of business leaders is seen as a principal-agent problem, with the share-owners of firms as principals. The hypothesis is that the owners use ethnic and demographic signals to select good 
agents. Finally, the third hypothesis is that male, white and mostly native-born Protestants from good families make good business leaders.

I provide evidence about these hypotheses that suggest strongly that the third hypothesis is correct, at least for current business leaders. It is too strong, however, to claim that these hypotheses have been tested in any serious sense. The problem is a complex one, and the data are scanty. This paper advances the discussion, but only begins the task of formulating testable hypotheses and subjecting them to test.

The paper proceeds as follows. I first survey the literature on the phenomenon to be explained, particularly the most recent confirmation of this pattern (Temin, 1997). Then I consider each of the hypotheses in turn, expanding the arguments and searching for evidence that can be used to test them. A conclusion reflects on the difficulty of answering important questions.

\section{The American Business Elite in Historical Perspective}

The question of who leads American business has been a concern for many years. As economic growth moved to the center of economic inquiry after the Second World War, the role of entrepreneurship came in for study. Schumpeter championed entrepreneurs in his accounts of economic development and creative destruction, and many scholars took their cue from him (Schumpeter, 1934, 1942). The Center for Entrepreneurial Studies at Harvard was established in the late 1940 s to investigate the nature of entrepreneurs and entrepreneurship. It quickly became engaged in controversy with classically-trained economists who focussed on natural resources and technology as the sources of economic growth, and it generated several historical studies of American entrepreneurs. (For more detailed history, see Abramovitz and David, 1997; 
Lamoreaux, Raff and Temin, 1997.)

Miller conducted one of the most well-known historical studies. He demonstrated that the leaders of American business around 1900 were overwhelmingly native-born Protestants from good families. The absence of women and people of color was not considered unusual enough to merit discussion. Instead the aim of the study was to refute Horatio Alger and historians who presented Andrew Carnegie as the archetypal American entrepreneur. A survey of political leaders around 1900 confirmed that they too were white, male, native-born Protestants from good families (Miller, 1949, 1950).

I replicated this study for business leaders today. I confirmed that the CEOs of the Fortune 500 companies in 1996 were still white, male and mostly native-born Protestants from good families. The two studies are compared in Table 1. It is not surprising that the business elite in 1900 lacked women, African Americans and Asian Americans. The surprise is that this is still true today. There have been one or two of each category among the CEOs of the Fortune 500 , so the parallel is not exact, and some of the first three entries in the second column of Table could be .02 instead of simply zero. There is one Asian American CEO of a Fortune 500 company. One of these companies had an African American CEO a few years ago, and a woman recently became $\mathrm{CEO}$ of another large firm. But there is no discernable trend toward the inclusion of these groups. The Avon Company recently passed over a woman candidate to appoint a male CEO (Wayne and Gilpin, 1997). If the ice is breaking, it has only cracked as yet.

This result is consistent with other studies that have confirmed this ethnic and demographic stability in the intervening century. Taussig and Joslyn conducted a study of business leaders in the 1920 s, before the Harvard center was established. They conducted a mail 
survey of 8,000 business leaders, asking only some of the same questions that Miller later posed. But they found substantially the same picture. They concluded that they could not talk of a business caste, but that their "data show a substantial amount of inbreeding within the class (Taussig and Joslyn, 1932, p. 239)."

Taussig and Joslyn did not assert that their results were temporary. They denied that the poor showing of the "lower social classes" to appear in the business elite was due to lack of opportunity. Instead they attributed the success of the male, white, Protestant well-born to "a fundamental inequality of native endowments (Taussig and Joslyn, 1932, p. 268)." I support their findings about the composition of the business elite, but want to disassociate myself from their explanation, as I will explain further below.

Their study was replicated in the 1950 s, reproducing their results about the influence of family, although finding more educated business leaders (Warner and Abegglen, 1955). By then, however, the absence of African Americans was worthy of note, and the authors of the new study remarked upon it and their expectation that it was only temporary: "Although today Negroes are rapidly entering business and producing a solid and important middle class, thus strengthening their integration with, and loyalty to, America, it will take another generation for Negro men of ambition to climb the hard route now followed by some of the sons of the white middle class (Warner and Abegglen, 1963, p. 227)." Table 1 shows that this optimistic expectation has not been realized.

Research on the American business elite has confirmed that its ethnic and demographic composition has not changed over the past century. This result does not appear to rely on the way the data were collected, nor on the size of the sample. The pattern is clear. I therefore can 
restrict my attention here to the small sample of CEOs I examined in the spirit of Miller's inquiry without apparent loss of generality. This restriction originates primarily in the difficulty of obtaining ethnic and demographic information in today's society. We are so firmly committed to the classless society that we do not collect and disseminate information about our origins. It is only by focussing this inquiry onto the very tip of the business pyramid that I have been able to compile the information that follows.

This study of social and economic mobility lies at one extreme of the American population. It is far from the usual question posed by most economists who look at mobility today. They focus on the acquisition of education, the great divide in the current widening of the income distribution (Levy and Murnane, 1992). It is even farther from the typical question posed by sociologists who examine mobility at the bottom of society (Jencks, 1972; Wilson, 1996). A study of the tip of the iceberg appears unrelated to these inquiries into the main body of the berg. But I will return to these questions and literatures in discussing the third hypothesis, arguing that these studies are relevant to the question of who gets to the very top.

To update Miller's study, I replicated his political sample as well as the economic one. The study of political leaders functions as a control group for the study of business leaders. But while Miller found that the two groups were indistinguishable in 1900 , I found that they were clearly different as we approach 2000. I studied the composition of the U. S. House of Representatives as a sample of top political leaders comparable to the CEOs of the Fortune 500 companies. I found, in sharp contrast to Miller, that the two groups were strikingly different, as shown in Table 2. There were women, people of color, and many Catholics among the Congressmen. In fact, the ethnic and demographic composition of the House is more like that of 
the population as a whole than like that of the business elite. Only the under-representation of women keeps it from mirroring the population completely. A study of the federal executive in the 1950 s found that they were more like the population at large than the business elite, consistent with the changes shown in Table 2 (Warner, et al., 1963, p. 37).

Changes in the political elite show that the stability of the business elite was not inevitable. Business leaders, like political leaders, could have changed as the American polity and economy changed. But they did not. The question to which this paper is addressed is why not.

\section{Discrimination}

A prominent line of thought argues that the long apprenticeship in business provides an opportunity for discrimination. Becker (1971) defined discrimination as a taste for working with similar people. If members of a company have such preferences, then it is no surprise that a particular ethnic and demographic group could reproduce itself over time. It may be surprising that this group could maintain its composition for an entire century. If the stockholders are losing potential returns because the management refuses to hire and promote the best people, the stockholders should object. This hypothesis argues that the will of the management is stronger than that of stockholders.

Discrimination could take place at many points in a manager's career. It might affect the probability of being hired as male WASPs (white Anglo-Saxon Protestants) indulged their taste to associate with other male WASPs. Once hired, similar discrimination could affect the probability of being promoted. It might even have more impact as a talented manager became more senior. This of course is the process that Becker described. The only difference is the 
common supposition that discrimination was practiced on the shop floor. But there is no reason why it cannot be practiced among managers as well. And if various discussions of discriminatory "ceilings" are to believed, discrimination is more likely to be observed in offices than on the shop floor. By the time a new CEO is chosen, discrimination along the way could have generated a pool of candidates whose ethnic and demographic characteristics have not changed in a century.

It is notoriously hard to test for discrimination. It typically is estimated as a residual (Blinder, 1973; Oaxaca, 1973). After all other characteristics have been allowed for, is there still an effect of like picking like? This procedure is impossible to use in this case because we lack a theory of entrepreneurship that would indicate what other variables should be entered, despite the work of the Harvard Center for Entrepreneurial Studies. Our ability to forecast who will be the CEO of a Fortune 500 company is very limited. Any discrimination would not be visible in the large errors from any equation that might be estimated.

Comparison of the business elite with the political elite provides a different way to test for discrimination. The political elite, as shown in Table 2, changed dramatically over the last century. It followed a different pattern than the business elite. If discrimination was practiced within large companies at all levels, then ethnic and demographic stability was preserved by repeated acts throughout managers' careers. If the political elite turns over more rapidly, then there would be more opportunities for new people to enter and less opportunity for each of them to be discriminated against.

This mechanism could be tested by examining the careers of the business and political elites. Most CEOs have spent long years in business, even in the same company that they now 
head. The question is whether members of the House of Representatives--the political elite as defined here--have been in politics or in the House as long. If they have, then there has been ample opportunity in that context also for senior party officials to express and implement any desire to associate only with similar people. If they have not, then the possible scope of discrimination is smaller in politics than in business. This negative finding then could explain the discrepancy between the composition of the business and political elites today.

Table 3 makes this comparison. The first row shows that almost one-third of current CEOs of the Fortune 500 have been in this job for a decade. But over four-fifths of these CEOs have been in the company for a decade. That is, half of the CEOs had been in the company for many years before becoming CEO. The second row makes the point even more strongly. Less than ten percent of CEOs have held that position for two decades, but 60 percent have been in the same company for that long. Fully half the CEOs have had very extensive careers in their firm before being appointed CEO. This pattern is of long duration. Half of business leaders in the 1950s had been executives at only one company, and an additional quarter were executives in only two companies (Warner and Abegglen, 1955, p. 127).

The right-hand side of Table 3 compares this experience to that of U. S. Representatives. The first row is virtually the same as for CEOs. Roughly one-third of Representatives have been in the House for a decade, but three-quarters have been in politics for that long. Almost half, in other words, were in politics before coming to the House. The second row reiterates this point only slightly less strongly than for CEOs. Less than ten percent of Representatives have been in the House for two decades, but 40 percent have been in politics that long. One quarter of congressional leaders in the 1960s had no other occupation than politics--up from only five 
percent professional politicians in the 1900s (Huntington, 1965, p. 16). Congress-people are made, not born.

The durability of members of Congress may be surprising. We hear in the news about newcomers to politics who win high office. The political process is heralded as being the most open in the world. Yet there is off-setting information. The chance of being re-elected once one enters the House is very high. The average re-election rate for Representatives in the last ten Congressional elections is 93 percent (Ornstein, Mann and Malbin, 1988, Table 2-7, p. 61). People running for the first time typically are chosen largely from the ranks of lesser office holders. Newcomers are newsworthy because they are unusual. As with foreign-born and uneducated managers, newcomers to the political field are the exception rather than the rule in the political elite.

Promotion also is determined by surprisingly similar processes in the corporate and Congressional worlds. CEOs tend to be appointed by their predecessors (Forbes and Pierce, 1991; Pinfield, 1995; Osterman, 1996). Similarly, appointment in the House and Senate to committee head with its resultant power and publicity is by the leadership of Congress. In fact, the corporate world may be more open for promotion than the political. The leadership of the top 500 companies is more scattered than the leadership of Congress; there are 500 independent firms. Similar opportunities to discriminate appear present in both spheres.

But the parallels between politics and economics are not exact. Politicians are selected in elections while CEOs are selected by share holders. It could be that the class of voters and shareholders are sufficiently different that they have different tastes in leaders. This argument is intriguing, but it has many problems. First, as noted above, the pool of candidates often has been 
determined by prior careers and presents a very restricted range of choice. Second, this argument moves away from Becker's concept of discrimination. Shareholders do not associate with CEOs. It is hard to construct an argument why they would forgo earnings on their stock to have a representative of their ethnic and demographic group on the cover of the company's annual report. Third, while we know a lot about who votes, we have very limited information on who owns stock. The growth of pension funds has created another level of intermediation to the financial system, making the concept of ownership unclear for this purpose. Stock ownership is far more widespread now than in 1900, but the composition of owners is not well known.

An alternate approach may avoid the problems inherent in the comparison of the business and political elites. Suppose there is another American business elite not characterized by long apprenticeship and its attendant opportunities for discrimination. This elite would be distinguished by its success in business, like the CEOs, but it would not consist only of people who had worked their way up large organizations. If this control group looks like Congress, that would suggest the presence of discrimination in the selection of business leaders. But if this control group looks liked the CEOs, then this suggests that discrimination is not needed to explain the ethnic and demographic make-up of the CEOs.

The control group that I have used is the Forbes list of the richest 400 people in the United States. These are people who have succeeded in making a lot of money through their activities in business. But they may or may not have been associated with large organizations. They may have made their money by any conceivable means. And they do not overlap significantly with the CEOs of the Fortune 500. Only 31 of the top 500 CEOs are among the richest 400 (Temin, 1997). 
There are some problems with this group that must be dealt with before making a comparison. One can inherit riches. To be born rich clearly does not indicate your ability to make waves in the business ocean. Those among the richest who inherited wealth therefore must be omitted from the sample. People identified as families in the list typically also have inherited their wealth. They too must be omitted unless active members of the family can be identified. One also can marry riches, and even marry someone who will become rich. These passive recipients of wealth are harder to identify. But it is clear that the estranged wife of Warren Buffert is among the richest 400 because she is counted separately from her husband, not because she earned the money herself. These people also should be excised from the sample, but it is not always possible to identify them. To minimize confusion, I leave them in the sample and discuss them as individual cases.

The purged group consists of 309 people. It was harder to find information about them than about the CEOs. They often did not have large companies behind them issuing biographical bulletins. They are less likely to appear in Who's Who, although one could argue that they deserve to be included at least as much as the CEOs. The sample is incomplete, and I assume that the rich people for whom information was not available have characteristics similar to those who are better known. Some characteristics, like gender and non-European background, are sufficiently public that my information is virtually complete.

Information on the richest 400 was gathered from Forbes publications about them, Who's Who, and scattered biographical information (Davis, 1997; Who's Who in America, 1997) . Religion was difficult to observe, as it was for the CEOs; only a few people on the list proclaimed their religion. I checked more specialized Who's Whos to no avail (Who's Who in 
American Jewry; Who's Who in the Catholic World). I therefore estimated the proportion of Catholics and Jews on the list by an examination of names. This is a noisy estimator, but it appears to work well in this case as it has in others (Lieberson and Carter, 1979). I tested the estimation procedure on the political elite. The religion of Representatives is documented. Allocating them to religion by name produced estimates that were off by only a few people. Comparing actual names, however, shows that this agreement was produced by offsetting errors in attribution. It follows that the method becomes less reliable as the sample size decreases. Results of these varied attempts to analyze the richest 400 are shown in Table 4, where "old" wealth is distinguished from "new" by whether a person on the list was also on the list ten years ago.

There are less than half the proportion of women on this list as in the House. In addition, while inherited wealth has been excluded, several women included in Table 4 are there because of their family rather than their individual accomplishments. Susan Buffert is the estranged wife of Warren Buffert, as noted above, and Abigail Johnson is part of the Johnson family that owns Fidelity Investments. Other women inherited much of their wealth or have achieved success with their husbands. There is no way to identify all these connections, and the estimates in Table 4 over-estimate the proportion of people achieving great riches who are women. The rich are much more like the business elite than the political elite in this dimension.

There is only one African American among the Richest 400: Oprah Winfrey. There are very few Asian Americans and Catholics. These characteristics too are characteristic of the CEOs rather than of Representatives. There are more Jews in this list, particularly among the "old" wealthy than in either the business or political elite. This recent decline in the number of 
Jews appears to be related to a switch from banking and finance as a source of wealth to what Forbes calls technology, but it is hard to know. Religious preference was identified by names, as noted above. While this appears to be a reliable method in the aggregate, there is a lot of noise in smaller samples.

With the exception of Jews, the richest 400 resemble the CEOs of the Fortune 500 far more than the members of Congress. It appears that both business elites are the same. It follows that the apprenticeship needed to become CEO of a large company is not the critical factor determining who gets to be at the top of the business world. Discrimination does not appear to provide an explanation for the stability of the American business elite, except possibly for Jews.

Because the existence of various "ceilings" is assumed widely, it is worth confronting their putative existence directly. Consider the "glass ceiling" that is reputed to keep women from top managerial positions. (I choose this ceiling to examine for reasons of data availability.) The hypothesis states that women are free to achieve progress until they bump up against the class ceiling, at which point their progress ceases. On the added, often implicit, assumption that women are as capable as men, they should be represented equally at all levels of economic activity below the glass ceiling. Specifically, they should be as prevalent among executives just below the glass ceiling as in the workforce as a whole and absent among the top CEOs above the glass ceiling.

The data do not confirm this picture. Women now comprise almost half the workforce (46 percent). They are absent among the top CEOs as shown in Table 1. But they are not as numerous below the putative glass ceiling as they are in other jobs. A census of women executives in the Fortune 500 companies revealed that only ten percent of corporate officers are 
women (Catalyst, 1996). Selection against women is being made lower down in the organization, below the assumed glass ceiling. The possibility that this was the result of discrimination during these women's careers cannot be ruled out, but appears unlikely from the comparison with the richest 400 . The glass ceiling, like discrimination in general, does not explain the stability of the American business elite.

\section{Principals and Agents}

We discuss business and political actors as if they are leaders, but they are more properly seen as our agents. In each case they are selected by a process designed to give principals-owners and citizens--an active role in their selection. We therefore can use principal-agent analysis to understand the composition of these groups.

Principal-agent theory has developed rapidly in the past few decades as economists have explored the types of contracts that can be made between principals and agents. From the agent's point of view, the contract should ensure him or her of being better off than he or she would be without entering into this principal-agent relationship. From the principal's viewpoint, the contract should align the interests of the agent and principal. The problem comes from the fact that the principal and agent possess different information, and they must negotiate with the other under uncertainty.

The theory typically takes the identity of the principals and agents as given. But a branch of this theory examines the choice of agents. The two questions are related through the information gathered in the choice of an agent. For if the principal has gathered information in the course of choosing an agent, the principal can make a better bargain. Greif (1994), for example, analyzed the choice of agents among medieval merchants. In one group, merchants 
shared information about potential agents; in another, they did not. The first group had more information about the agents and could use that information in making contracts. In Grief's case, the well-informed merchants (principals) could pay lower wages without inducing the agents to cheat on them.

Often it is hard to obtain the information needed to select the best agent. Sometimes there is no individual information about the candidates in question at all. Principals need in this case to seek clues about the relative merits of different candidates. They look for signals that might help them make an educated guess about the relative merits. These signals could be the classic ones studied by Spence $(1973,1974)$. A signal in this sense has two characteristics. It is costly to obtain, so that not everyone has it. And it is positively correlated with the ability desired in the agent. Education is the classic case.

One important and relevant point in this literature is what happens in education. Do students actually learn something useful? Or do they simply work hard to give a signal that they are bright people? In the former case, human capital corresponds to any other productive asset. In the latter, people succeed only in sending a signal; they do not acquire any useful skills in education. The literature is hardly conclusive, suggesting strongly that education performs a variety of functions. But there seems little doubt that one of these functions is signaling the worth of their graduates. Attending an Ivy League college, for example, could signal a potentially successful CEO. Leaving education behind, perhaps being a male WASP is a good signal as well.

This signaling may be important for the initial hiring practices of large companies, but the CEOs of the Fortune 500 are near sixty years old. Their education was completed long ago. 
However important a signal their ethnic and demographic group communicated when they got their first or their first few jobs, those characteristics and their education could not be a good signal about the abilities now. Far better is their performance since then, since they entered business. As shown in Table 3, almost all of these CEOs had a long track record in business-typically in the same firm they would lead--that could be evaluated to provide a better signal for their future performance as $\mathrm{CEO}$ than their ethnic and demographic characteristics. Reworking the same data shows that on average these CEOs were in their firm for 15 years before becoming CEO (Davis, 1997). Many CEOs who lack such a track record are those who have been CEOs for years and years. They typically founded the company they now head and grew with it. They have not been chosen anew to be CEO, only not rejected for their recent performance.

The prior careers of the CEOs therefore can be seen as an apprenticeship where they had ample opportunity to signal their abilities to the principals who select CEOs. Ability is hard to signal in a business environment; there is a lot of noise that is difficult to separate out. A short apprenticeship might show candidates who had been lucky in addition to those who were skilled. A longer apprenticeship is able to provide more observations of ability and reduce the variance due to luck. It also reduces the value of signals acquired when young. Superiors in large firms have adequate opportunity to judge their juniors by performance, reducing their need to use less precise signals for ability.

Politicians signal their abilities for as long a time as businesspeople. They have a long apprenticeship in politics just as businesspeople have in business, as shown in Table 3 . The difference between these two elites cannot be due to lack of information on the part of the electorate, that is, on the part of the political principals. It is highly unlikely that a signaling 
argument in a principal-agent framework can explain the differing trajectories of the business and political elites. The presence of elections in the political arena provides a way for new and untried Representatives to emerge, but, as noted above, there is almost no involuntary turnover. Although the speed of ascent may be slightly faster in politics than in business, the prevalence of new faces is no greater.

Before leaving this topic, it may be worth noting that this hypothesis has opposite implications from the discrimination analysis. If discrimination is the key to the stability of the economic elite, this elite is less skilled than it would be in the absence of discrimination, for if they were the most skilled choices, there would be no discrimination. Only if a choice involves some cost to preserve ethnic or demographic homogeneity do we regard it as discrimination. In that case, the business elite, being the product of discrimination, is less well chosen than the more open political elite. In the case with signaling, the business elite is well chosen; it is superior in skill and ability to the more randomly chosen political elite. Even though apprenticeships are long in both fields, the importance of elections in political careers introduces enough randomness to cloud the signals that come from class and caste identification.

\section{Ability}

If the evidence suggests that the stable composition of the American business elite is not due either to discrimination or to signaling, then this stability may be due to the ability of this group to perform well in American business. That inference, reached by a process of elimination, raises a very important question in its wake. Why should white, male WASPs be better at business than others?

Taussig and Joslyn concluded that differences in business success have their "origins in a 
fundamental inequality of native endowments, rather than in an inequality of opportunity (Taussig and Joslyn, 1932, p. 268)." I reject any genetic arguments out of hand. First, businessmen in other parts of the world do very well and come from entirely different genetic pools. Second, racial theories have consistently been proven wrong in the past, but often not before causing extensive misery and mayhem. Taussig and Joslyn wrote before the Nazis took power in Germany; their racist conclusions were reached before appreciation of their implications had become horribly clear.

Instead, I suggest that the educational system of this country has tended to favor this group disproportionately, giving them an advantage in the race to the top. This may appear to be an odd argument in this land of universal education. The vast majority of people who do not become CEOs of the Fortune 500 companies are not illiterate nor uneducated. But a variety of evidence suggests that minority groups in this country receive education that is not as good as that bestowed on the favored class.

This argument therefore descends into the murky world of the quality of education. No one can be ignorant of the recent jeremiads about the quality of American education nor of the attacks on the system of education that is thought to be at fault. I will draw on this literature to argue that the distribution of education across ethnic and racial groups is unequal. Despite a century or more of attempts to provide equal educational opportunities to all Americans, the result is still a system that perpetuates the loose hierarchy that has characterized the American business elite for that time.

With this turn in the argument, I connect with the more typical discussion of mobility. I argue that the broad trends noted by others have effects on the small population I discuss. It is an 
unusual occurrence for any individual to join any of the elites at the top of American economic and political society that I have described. But, as I have shown, membership in these groups has not been random. It follows that movements among broad aggregates of the population have effects even on the composition of people at the very top. But we must remember that the connection is very loose because it is such a rare event for anyone to join the elite and therefore must be determined largely by factors we cannot observe.

I examine evidence of three types. First, the starting point around 1900 was unequal. Second, while the many efforts to reduce this inequality have made great strides, the result has been only an incomplete victory. And third, current proposals to deal with the resulting problems of education appear unlikely to reduce educational equality further and may well increase it.

A century ago, educational opportunities were limited for both women and African Americans. Exceptional individuals could overcome these handicaps and achieve distinction, but the poor educational environment in which they grew up reduced the number of women and African Americans who could attain these heights. The inequality of "separate but equal" education for African Americans was exposed half a century ago in Brown v. Board of Education when the separate system was declared illegal. Women generally were denied access to higher education at this time as well.

The past century, and particularly the last half-century have seen many heroic attempts to break down the barriers between groups and assure every American child equal access to education. And the gains have been spectacular. African Americans have access to all schools, and women have reached parity with men in many institutions of higher learning. I do not mean 
to deny or degrade these noteworthy accomplishments. I only want to say that they are as yet incomplete and that the path to completion is not at all clear.

It appears to be common knowledge that non-white groups receive less good education than whites even today, but this presumption is hard to verify. Aside from the problem of gathering data about the quality of education, the data to be gathered lack definition. If we define school quality as that attribute that generates members of the business elite, we are engaging in circular reasoning. Measuring school quality by standardized testing of graduates has many problems as well. And attempts to look at intrinsic qualities of education have not yielded a consensus on even simple questions, such as whether small class size improves education or not.

Despite these conceptual and empirical difficulties, there is a general consensus that urban schools and schools in low-income areas are less good than schools in suburban and wealthy school districts. A recent study of the black-white wage gap found that scores on the Armed Forces Qualification Test were potent predictors of wages. More importantly, use of these scores sharply decreased the size of a race dummy in wage equations. The authors concluded, "that the disadvantages young black workers now face in the labor market arise mostly from the obstacles they faced as children in acquiring productive human capital (Neal and Johnson, 1996, p. 871)." Education Week dramatized parallel but less careful findings in a recent report, saying: "Achievement in urban districts is abysmal, raising troubling questions about the future of the 11 million children who attend urban public schools (Education Week, 1998)."

Blacks and Hispanics continue to have lower average incomes than whites, although the dispersion of incomes in these groups is wide. The average family income of these groups is between one-half and two-thirds of the white level. Trends toward equalization of incomes and 
wages have been halted in recent decades, specifically since 1980 (Levy, 1995, pp. 41-43, Neal and Johnson, 1996, p. 891). These wage and income difference must be due in part to the difference in educational attainment, but causation must work in the opposite direction as well. As noted by Education Week, schools are the victims of poor neighborhoods, but bad schools also help create--and perpetuate--bad neighborhoods (Education Week, 1998). The evidence on income therefore is consistent with the educational information. It does not however provide much additional data on the causes of demographic stability among the business elite.

Turning to higher education, the proportion of men earning a bachelor's degree from college has risen from less than ten percent of the cohort born around 1900 to over 30 percent for the cohort born just after World War Two. This proportion has fallen more recently, as men ceased going to college to avoid military service in Vietnam and as immigrants with low education diluted the contribution of the college-educated. Women followed men at about a generation remove, reaching a maximum of about 25 percent. As the proportion of men receiving bachelor's degrees has fallen, the proportion of women has passed that of men (Mare, 1995, pp. 164-66). These aggregate data suggest that the educational deficit of women has disappeared, but they are misleading to the extent that the dilution effect of immigrants dominates the proportion of men.

Other demographic groups have lower educational attainments than whites, considering men and women together. Asians, both native-born and immigrants have higher college completion rates than whites--making their low representation in the business elites doubly problematical. But African Americans and Hispanic Americans, both immigrants and nativeborn, have far lower college attendance rates--less than ten percent (Mare, 1995, p. 174). This 
educational deficit provides an important reason why these groups are under represented among the business elite.

It hardly is news to note that blacks are less likely to attend college than whites. And existing trends do not suggest that blacks will have an easier time entering leadership groups in the future. The trend of college attendance among blacks increased in the 1960s and 1970s, that is, in the cohort just following the one surveyed here. But black college entry declined after 1977 while white college attendance rose. The result is that now the proportion of white young men (and women) who attend college is substantially larger than the proportion of blacks. The interruption in the growth of college attendance among black men suggests that there is little prospect that there will be more than an occasional black among the business elite in the years to come.

There are many hypotheses, but few explanations, for this interruption in trend (Hauser, 1993). One possibility is simply that the cost of college education has risen. Private college tuition has been rising rapidly in the 1980s (Clotfelter, 1991). But although this increase has raised the cost of a college education, the largest cost of attending college is the foregone earnings while attending school. This is particularly true for the large and increasing proportion of college students attending public colleges and universities. One aspect of the growing wage disparity has been that wages of high-school graduates have stagnated (Levy and Murnane, 1992). The total cost of college education therefore has not risen nearly as fast as tuition--if at all.

In contrast, the return to college education started to rise dramatically in the late 1970 s, just at the time the proportion of black youth attending college stopped rising. . The question is 
why the greater attractiveness of a college education in terms of future earnings has not continued to attract blacks to college. One possibility is that liquidity constraints have become more important over time. All people find it hard to borrow on their future earnings since these earnings are highly uncertain. Low wages for high-school graduates make it hard to accumulate savings. In addition, the government has been retrenching on its commitment to offset these market problems with public policies. Affirmative action and college loans were part of the Democratic program in the 1960s and 1970s. They have been reversed by the Republicans, and do not seem to have many supporters in either party today. Lack of liquidity and of government support appear to have conspired to limit the number of blacks in college.

As noted above, educational differences cannot explain the absence of women among the business elite. They may provide some support for the absence of women in current elites, but they suggest that the future will be one of inclusion. This prediction is at sharp variance with the pessimistic prediction about African Americans. But it should be noted that interviews of women among top management of American corporations does not reveal confidence in such a hopeful prediction. These women see themselves as nontraditional managers, making their career paths not simply a matter of inclusion in a group, but also a vehicle for change among managers. A recent book based on such interviews concludes: "Although both senior executives and their organizations may now be more aware of the obstacles facing women and other nontraditional managers, the belief that it is 'only a matter of time' may still be more myth than reality (Morrison, White and Van Velsor, 1992, p. 156)." Even though the evidence does not support the existence of glass ceiling, it is clear that these authors believe in it.

Conclusions about the future careers of women managers therefore are highly suspect. 
Similarly, the under representation of Asians and Catholics among the business elite remains hard to explain and therefore equally hard to extrapolate. We therefore may hope for increasing diversity among the business elite without going to far as to predict it.

\section{Conclusions}

This paper begins the exploration of a difficult topic. It has formulated alternative hypotheses and marshaled data relevant to them. But it cannot be maintained that these data are sufficient to do more than point in the direction of one hypothesis. While the question of who gets to be included in the American business elite is important, answers are hard to come by.

This difficulty arises from many causes. The first is the dominant American ideology, which indicates that every person has an equal shot to be President or the head of Microsoft or General Motors. The former is more likely than the latter, as shown above, but the ideology blinds us to demographic determinants of elite composition. Ideology also results in scarce data, because no one wants to collect apparently irrelevant data. Even more to the point, members of the elite do not routinely supply data about their origins that would have been essential components of their biography in prior generations. Finally, connected to the strong ideology and weak data, emotion runs high in discussions of these matters. One has only to glance at the popular press when a new member joins the American business elite to see that these are not dry, academic questions issues. Emotion often is the enemy of reason.

Despite these obstacles, this paper presents evidence on possible reasons for the surprising demographic stability of the American business elite. The evidence suggests that the stability of the business elite is not now due to discrimination or signaling. Instead, it appears to derive from unequal access to educational resources, where education is to be understood in a 
broad sense. This conclusion, however, is only a limited one. The unequal access to education is at least partly the result of past discrimination, as explained above. As a result, the picture is far more complex. Discrimination then is the Aristotelian "final cause," while better education is the "proximate cause." Depending on which kind of cause is at issue, reasonable people then can disagree about the "cause" of the surprising stability of the American business elite. It is the possibility of such theoretical disagreements and the paucity of data with which to confront alternative theories that makes this paper only a small step on the long road to answering the question posed. 


\section{Table 1}

The American Business Elite

(percent)

\begin{tabular}{||l|l|l|}
\hline & $1900 \mathrm{~s}$ & $1990 \mathrm{~s}$ \\
\hline Women & 0 & 0 \\
\hline African Americans & 0 & 0 \\
\hline Asian Americans & 0 & 0 \\
\hline Immigrants & 10 & 5 \\
\hline Catholics & 7 & $5-10$ \\
\hline Jews & 3 & $2-10$ \\
\hline
\end{tabular}

Source: Temin, 1997. 
Table 2

The American Political Elite

(percent)

\begin{tabular}{||l|l|l||}
\hline & $1900 \mathrm{~s}$ & $1990 \mathrm{~s}$ \\
\hline Women & 0 & 12 \\
\hline African Americans & 0 & 8 \\
\hline Asian Americans & 0 & 1 \\
\hline Immigrants & 6 & 2 \\
\hline Catholics & 4 & 29 \\
\hline Jews & 2 & 6 \\
\hline
\end{tabular}

Source: Temin, 1997. 
Table 3

Duration of Business or Political Career

(percent)

\begin{tabular}{||l|l|l|l|l||}
\hline & \multicolumn{2}{|c|}{ Business Elite } & \multicolumn{2}{c|}{ Political Elite } \\
\hline & as CEO & in company & in House & in politics \\
\hline 10 years experience & 29 & 83 & 31 & 75 \\
\hline 20 years experience & 8 & 60 & 8 & 41 \\
\hline
\end{tabular}

Note: The number of observations is 478 for the business elite; 309 , for the political elite.

Source: Davis, 1997; http://www.house.gov:80/MemberWWW.html. 


\section{Table 4}

The Richest Non-inheriting People

(percent)

\begin{tabular}{||l|l|l|l||}
\hline & Total & Old Wealth & New Wealth \\
\hline Women & 5 & 3 & 5 \\
\hline African Americans & 0 & 0 & 1 \\
\hline Asian Americans & 1 & 0 & 3 \\
\hline Immigrants & 7 & 7 & 8 \\
\hline Catholics & 5 & 6 & 5 \\
\hline Jews & 17 & 24 & 10 \\
\hline
\end{tabular}

Note: The division between old and new was being among the Richest 400 ten years previously

(in 1987). Subtracting people identified by Forbes as inheriting their wealth left 148 old rich and 161 new rich.

Source: Forbes Magazine, 1987, 1997; Davis, 1997. 


\section{References}

Abramovitz, M., and P. A. David, "Convergence and Deferred Catch-up: Productivity Leadership and the Waning of American Exceptionalism," in R. Landau, T. Taylor, and G. Wright (eds.), The Mosaic of Economic Growth (Stanford, 1996), 21-62.

Becker, Gary S., The Economics of Discrimination. Second Edition (Chicago: University of Chicago Press, 1971).

Blinder, Alan S., "Wage Discrimination: Reduced Form and Structural Estimates," Journal of Human Resources, 18 (Fall 1973), 436-55.

Catalyst, 1996 Catalyst Census of Women Corporate Officers and Top Earners (New York: Catalyst, 1996).

Chandler, Alfred D. Jr., The Visible Hand (Cambridge, MA: Harvard University Press, 1977).

Chandler, Alfred D. Jr., Scale and Scope (Cambridge, MA: Harvard University Press, 1990).

Clotfelter, Charles T., Economic Challenges in Higher Education (Chicago: University of Chicago Press, 1991).

Davis, Jonathan T., ed., Forbes Richest People: The Forbes Annual Profile of the World's Wealthiest Men and Women (New York: John Wiley and Sons, 1997).

Education Week, Quality Counts '98 (New York, 1998).

Forbes, J. Benjamin, and James L. Piercy, Corporate Mobility and Paths to the Top (New York: Quorum Books, 1991).

Forbes Magazine, "The Richest People in America: The Forbes Four Hundred," October 5, 1987.

Forbes Magazine, "The Richest People in America," October 13, 1997. 
Greif, Avner, "Cultural Beliefs and the Organization of Society: A Historical and Theoretical Reflection on Collectivist and Individualist Societies," Journal of Political Economy, 102 (October 1994), 912-50.

Hannah, Leslie, "Survival and Size Mobility Among the World's Largest 100 Industrial Corporations," American Economic Review: Papers and Proceedings, 88 (May 1998a), 62-65).

Hannah, Leslie, “Marshall's 'Trees' and the Global 'Forest': Were 'Giant Redwoods' Different?" in Naomi Lamoreaux, Daniel Raff, and Peter Temin (eds.), Learning by Doing in Markets, Firms, and Nations (Chicago: University of Chicago Press, forthcoming, 1998b).

Hauser, Robert N., "College Entry Among African Americans," in Paul M. Sniderman, Philip E. Tetlock, and Edward G. Carmines (eds.), Prejudice, Politics, and the American Dilemma (Stanford: Stanford University Press, 1993), pp. 271-306.

Huntington, Samuel P., "Congressional Responses to the Twentieth Century," in David B. Truman (ed.), The Congress and America's Future (New York: Columbia University Press, 1965).

Jencks, Christopher, Inequality: A Reassessment of the Effect of Family and Schooling in America (New York: Basic Books, 1972).

Lamoreaux, Naomi R., Daniel M. G. Raff and Peter Temin, "New Economic Approaches to the Study of Business History," Business and Economic History, 26 (1997), 57-79.

Levy, Frank, "Incomes and Income Inequality," in Reynolds Farley (ed.), State of the Union: America in the 1990s, Vol 1, Economic Trends (New York: Russell Sage Foundation, 
1995), pp. 1-57.

Levy, Frank, and Richard J. Murnane, "U.S. Earnings Levels and Earnings Inequality: A Review of Recent Trends and Proposed Explanations," Journal of Economics Literature, 30 (September 1992), 1333-81.

Lieberson, Stanley, and Donna K. Carter, "Making It in America: Differences Between Eminent Blacks and White Ethnic Groups," American Sociological Review, 44: 347-66 (June 1979).

Mare, Robert D., "Changes in Educational Attainment in School Enrollment," in Reynolds Farley (ed.), State of the Union: America in the 1990s, Vol 1, Economic Trends (New York: Russell Sage Foundation, 1995), pp. 155-213.

Miller, William, "American Historians and the Business Elite," Journal of Economic History, 9, No. 2 (November 1949), reprinted in William Miller (ed.), Men in Business (New York: Harper and Row, 1962), pp. 309-28.

Miller, William, "The Recruitment of the American Business Elite," Quarterly Journal of Economics, 44, No. 2 (May 1950), reprinted in William Miller (ed.), Men in Business (New York: Harper and Row, 1962), pp. 329-37.

Morrison, Ann M., Randall P. White, and Ellen Van Velsor, Breaking the Glass Ceiling: Can Women Reach the Top of America's Largest Corporations? (Reading, MA: AddisonWesley, 1992).

Neal, Derek A., and William R. Johnson, "The Role of Premarket Factors in Black-White Wage Differences," Journal of Political Economy, 104 (October 1996), pp. 869-95.

Oaxaca, Ronald, "Male Female Wage Differentials in Urban Labor Markets," International 
Economic Review, 14 (October 1973), 693-709.

Ornstein, Norman J., Thomas E. Mann, and Michael J. Malbin, Vital Statistics on Congress, 1997-1998 (Washington, DC: Congressional Quarterly, 1998).

Osterman, Paul, Broken Ladders: Managerial Careers in the New Economy (Oxford: Oxford University Press, 1996).

Pinfield, Lawrence T., The Operation of Internal Labor Markets (New York: Plenum Books, 1995).

Schumpeter, Joseph A. The Theory of Economic Development: An Inquiry into Profits, Capital, Credit, Interest, and the Business Cycle (Cambridge, Mass., 1934).

Schumpeter, Joseph A., Capitalism, Socialism and Democracy, (New York: Harper \& Bros., 1942).

Spence, Michael A., "Job Market Signaling,"Quarterly Journal of Economics, 87 (August 1973), 355-74.

Spence, Michael A., Market Signaling (Cambridge, MA: Harvard University Press, 1974).

Taussig, F. W., and C. S. Joslyn, American Business Leaders: A Study in Social Origins and Social Stratification (New York: Macmillan, 1932).

Temin, Peter, "The Stability of the American Business Elite," paper presented at a conference on Elites, Minorities and Economic Growth, Israel, June 1997, NBER Historical Paper 104, October 1997.

Warner, W. Lloyd, and James C. Abegglen, Occupational Mobility in American Business and Industry (Minneapolis: University of Minnesota Press, 1955).

Warner, W. Lloyd, and James C. Abegglen, Big Business Leaders in America (New York: 
Atheneum, 1963).

Warner, W. Lloyd, Paul P. Van Riper, Norman H. Martin, and Orvis F. Collins, The American Federal Executive (New Haven: Yale University Press, 1963).

Wayne, Leslie, and Kenneth N. Gilpin, "Avon Calls on a Man to Lead It: Female Executives Passed Over for Top Spot," New York Times, December 12, 1997, p. 1.

Who's Who in America (New Providence, NJ: Marquis, 1995).

Who's Who in American Jewry (Standard Who's Who, 1980).

Who's Who in the Catholic World (Intercontinental, 1981).

Who's Who in Finance and Industry (New Providence, NJ: Marquis, 1995).

Wilson, William J., When Work Disappears: The World of the New Urban Poor (New York: Knopf, 1996).

Internet sources:

http://www.house.gov:80/MemberWWW.html http://www.edweek.org/sreports/qc98/intros/in-toc.htm 